\title{
Article \\ Shaping the Safety Culture of High Reliability Organizations through Digital Transformation
}

\author{
Marek Jabłoński (D) and Adam Jabłoński *(D) \\ Faculty in Chorzów, WSB University in Poznan, Sportowa 29, 41-506 Chorzów, Poland; \\ marek.jablonski@ottima-plus.com.pl \\ * Correspondence: adam.jablonski@ottima-plus.com.pl
}

Citation: Jabłoński, M.; Jabłoński, A. Shaping the Safety Culture of High Reliability Organizations through Digital Transformation. Energies 2021, 14, 4721. https://doi.org/10.3390/ en14164721

Academic Editors: Ewa Glińska, Urszula Ryciuk and Halina Kiryluk

Received: 1 July 2021

Accepted: 2 August 2021

Published: 4 August 2021

Publisher's Note: MDPI stays neutral with regard to jurisdictional claims in published maps and institutional affiliations.

Copyright: (c) 2021 by the authors. Licensee MDPI, Basel, Switzerland. This article is an open access article distributed under the terms and conditions of the Creative Commons Attribution (CC BY) license (https:// creativecommons.org/licenses/by/ $4.0 /)$.

\begin{abstract}
The aim of the article is to present key mechanisms for shaping the safety culture of high reliability organizations through digital transformation, which is now a key challenge for the entire global economy. It is particularly important in processes conducted by so-called high reliability organizations. From this cognitive perspective, it is important to define the place and role of digital transformation in shaping the safety culture of high reliability organizations. The comparison of the issues of the safety culture and digital transformation of high reliability organizations seems to be an important cognitive aspect resulting from technological progress in the area of the digital economy. The socio-technological system in which high reliability organizations exist is organized in such a way that all technical, operational and organizational aspects, including the participation of many entities involved in the operation of this complex system, are coherent. This coherence can be influenced by the digital transformation solutions that are implemented and used. The article used the analytic hierarchy process (AHP) and Vester methods, which were used for research by railway undertakings operating on the Polish railway market, to solve the scientific problem. A ranking of specific issues responsible for building safety culture and the identification of factors that are important for the effectiveness of the process of shaping the expected safety culture was created.
\end{abstract}

Keywords: safety culture; high reliability organization; digital transformation; digital economy

\section{Introduction}

Digital transformation is now a key challenge for many sectors of the economy and affects many aspects of the functioning of an organization. The processes of digital transformation are also important in the context of shaping organizational culture where changes in behavior determine other ways of building interpersonal relationships, especially in socio-technological systems. Safety culture within the framework of complex system theories is fundamental to ensure the sustainable development of organizations where many activities should be integrally coherent and shared by key personnel underpinning the smooth operation of the organization. The socio-technological systems of high reliability organizations appear particularly important for observing the impact of digital transformation on the development of the safety culture. These organizations are cognitively interesting research subjects, especially because of the importance of these organizations to their economies at regional, national and international levels. The digital transformation of these organizations must influence the processes of shaping safety culture within their scope. How, to what extent and how deeply it affects this safety culture has become the subject of scientific research discussed in this article. The research problem presented in this article is an assessment of the processes for shaping the safety culture of high reliability organizations through digital transformation, which now seems to be a determinant of changes in a significant number of areas of business activity. The aim of the article is to present the results of research into mechanisms for shaping the safety culture of high reliability organizations through digital transformation. 
The subject of the article concerns the place and role of digital transformation in shaping the safety culture of high reliability organizations. The scope of the article covers theoretical aspects, analytical theories and the results of scientific research conducted in the rail transport sector representing a group of high reliability organizations. High reliability organizations (HROs) have a distinctive attribute and operate almost flawlessly in dangerous, complex and uncertain environments [1]. HROs constantly search for errors that indicate that they can lead to major failures, and believe that if they are identified and the response to these warnings is appropriate, such disasters may be prevented [2]. High reliability organizations (HROs) are such organizations that usually operate in hazardous environments where the consequences of failure are extremely high [3].

Comparing the issues of the safety culture and digital transformation of high reliability organizations seems to be an important cognitive aspect resulting from technological progress in the area of the digital economy. The determinants resulting from digital transformation processes should be taken into account in shaping safety culture due to the change in the nature of work and the role of safety-critical workers when the share of digital solutions in operational processes is increasing. The socio-technological system in which high reliability organizations operate is organized in such a way that all technical, operational and organizational aspects, including the participation of many entities involved in the operation of this complex system, are coherent. This coherence can be achieved through the implementation and use of the effective and efficient solutions of the digital economy.

The approach used in the article presents an important research gap, which concerns the relationship between important components in the interdependence system of safety culture-digital transformation-high reliability organizations. It can be assumed that the principles and requirements of high reliability organizations in terms of "Zero Accidents" can be fulfilled by building and developing a safety culture supported by innovative solutions for the digital transformation of technologically and socially complex interactive and dynamic systems. Innovation is particularly important in this case. It includes open and closed organizational and technological innovations at the level of a wide stream of processes and projects conducted by high reliability organizations. The research gap is particularly important when it comes to shaping a positive safety culture and creating a well-configured, effective and efficient architecture of complex socio-technological systems.

The structure of the article is as follows. The article is divided into two logically linked sections, namely the theoretical and research sections. The article begins with the introduction. In the theoretical section, the place and role of high reliability organizations as key entities embedded in socio-technological ecosystems is discussed first. Subsequently, digital transformation and the specificity of a high reliability organization are presented. In the next part, the focus of the scientific discussion is on human and organizational factors-HSIs (human-system interfaces) in the digitalization processes of high reliability organizations. Then, the safety of the technical systems of high reliability organizations and process safety based on digitalization and the safety culture of a high reliability organization are discussed. Occupational health and safety in shaping the safety culture and the digitalization of high reliability organization processes are also important issues discussed herein. The research section presents the research methodology and the research results, including prioritizing key factors in the process of shaping the safety culture of high reliability organizations through digital transformation by means of the analytic hierarchy process (AHP) method, identifying key factors in the process of shaping the safety culture of high reliability organizations through digital transformation using the Vester method, quantitative research-surveys. The article ends with the conclusions and bibliography.

\section{High Reliability Organizations as Key Entities Embedded in Socio-Technological Ecosystems}

The multidimensional observation of dynamic social and technological changes shows a specific ecosystem which, through exposure to many disruptions in both social and 
technological dimensions, creates a picture of today's organization of the future. Undoubtedly, these are the so-called high reliability organizations. This ecosystem has a particular design because the set of aggregate components that constitute it provides an effective and constructive comparison of technical and social components aimed at fulfilling numerous functions in a given achievement of the objectives of the organization that create it. One of the key goals is to ensure a high level of safety in achieving the organization's business objectives.

Management of high reliability organizations is characterized by five key principles that facilitate, in particular, problem detection and analysis. In order to detect the problem of high reliability organizations, the following should be taken into account:

(a) the area affected by the failure: the use of a failure and a direct failure as a means of gaining insight into the strengths and weaknesses of the system;

(b) reluctance to simplify: avoiding tendencies to minimize or explain problems;

(c) vulnerability to action: awareness of the "big picture" and, in particular, how all elements of work fit together and how problems in one area can spread to other areas.

In the case of problem management, the high reliability organization takes into account:

(a) resilience: developing the ability to deal with unexpected events;

(b) respect for specialist knowledge: understanding where specialist knowledge is in the organization and ensuring that experts make decisions on how to solve problems.

The design of resilient technical systems in the reliability criterion is a priority [4]. Resilience becomes the dominant issue in research on safety and organizational practice [5].

By introducing these principles into a set of everyday processes and practices, HROs repeatedly and continuously shape and transform the binding safety culture. Reference should be made to the fact that, firstly, high reliability is not a state that an organization can ever fully achieve; rather, it is something the organization seeks and strives for. Secondly, reliability is of fundamental importance as a dynamic set of properties, actions and responses [6].

High reliability organizations are the best example of a system approach. They predict the worst and are prepared to deal with it at all levels of the organization. It is difficult, even unnatural, to remain chronically anxious, so their organizational culture takes on a deep meaning. People may forget fear, but the culture of a high reliability organization provides them with important reminders as well as such tools that help them to remember them. In the case of these organizations, the pursuit of safety is not so much about preventing individual human or technical failures but making the system as reliable as is practically possible in the face of threats to humans and the system. Safety culture, then, is an organizational aspect of the national culture, which is intended to influence the attitudes and behavior of members in relation to the organization's current health and safety performance [7]. High reliability organizations are not immune to adverse events but have learned to transform these occasional failures into increased system resilience [8]. Any indication by personnel performing safety-critical tasks of any event that could eliminate any disruption that could be a source of loss of health or human life is appreciated. Not all organizations view this as a positive factor [9]. A positive and just safety culture should therefore be developed [10]. Understanding and conscious management of organizations that satisfy the criteria described above makes it possible to harness complex technological processes and their relationships with the internal and external environment and give them an ontological character.

\section{Digital Transformation and the Specificity of a High Reliability Organization}

Operating in a dynamic, interactive socio-technological ecosystem, companies managed in a modern way are obliged to use organizational and management mechanisms and create innovative technological solutions to perform their key business functions. For many sectors, these business functions should generate high efficiency of organizations on the one 
hand and high reliability on the other. From this perspective, the constructive comparison of simultaneous, cumulative fulfilment of the criteria of efficiency and reliability shapes the image of safe organizations. The fulfillment of these assumptions requires the application and use of the latest trends in the economy, especially due to the fast-growing digital transformation. Digital transformation nowadays affects every sector of the economy and industry, but it is particularly visible in sectors composed of high reliability organizations, where dynamic processes and projects ensure the ability to achieve economic objectives in a secure way. Digitalization of processes is defined here as the integration of digital technologies into process operations in order to achieve greater efficiency and better product quality [11]. It is not necessary to mention that the implementation of the digital transformation in an often difficult organizational space requires considerable prior preparation and a great number of guidelines. However, this implementation remains the most specific phase of the entire transformation of the project. The change will be felt and visible to different types of stakeholders. How quickly this change will be concrete depends on how motivated and committed stakeholders are to the common issue of digitalization [12]. It should be borne in mind, however, that digitalization also entails new and increased risks pertaining to the implementation of innovations of business models resulting from interdependence in the ecosystem [13]. It can even be concluded that the digital transformation and the resulting innovation of business models have fundamentally changed consumer expectations and behavior, exerted pressure on traditional companies and distorted many markets [14]. The creation and implementation of digital technological solutions in every process and project determines their operational continuity and technical capacity and their safe integration. From this perspective, the digital transformation and its models of creating solutions can become a powerful accelerator of change and an accelerator of new values in many types of organizations, aiming to fulfill their refined principles, criteria and attributes of a high reliability organization. However, the problem of capturing value for innovators in the digital economy poses some other challenges than in the industrial economy. It inevitably requires an understanding of the dynamics of platforms and ecosystems [15]. In this context, the digital supply chain ecosystem is of particular importance, which should accurately reflect the needs and circumstances of the economy sector concerned [16]. It must be safe in terms of the performance of both safety-critical tasks and protection against cyber-attacks and any interference with secure technical systems. The mechanisms of these links must be strongly integrated [17].

\section{Human and Organizational Factors-HSIs (Human-System Interfaces) in the Digitalization Processes of High Reliability Organizations}

The most important resources of an organization are its people. Human consciousness determines their behavior [18]. People in the organization are its most important subject and strategic link. It allows organizational, technical and operational resources to transform into the value generated and delivered to the customer. In this context, a person in an organization should be viewed through the prism of his or her actions and personal and individual behavior and through the prism of human relationships from a team-based perspective. Work processes are influenced by technical, organizational and human factors. Technical factors include the construction and technical condition of machines, devices and equipment, workstations and the material working environment. Organizational factors include working methods, supervision, workstation organization and the organization of operational processes. The human factor, on the other hand, is preparation for work (qualifications and competencies), adaptation to work, state of health, psychophysical condition and attitude to work [19]. The human factor should also be considered in terms of the human ability to learn in their professional life cycle. The inability to learn from experience can lead to a chain of errors that can in turn lead to catastrophe [20]. The problem of human error can be considered in two ways: according to the individual and system approaches. Each of these approaches has its own model of causality of errors and each model gives rise to a completely different philosophy of error management [8]. In practice, the following phrase is popular: an unreported error is an error that will 
happen again. Therefore, all incidents must be handled responsibly as they precede disasters. People management therefore requires a high level of managerial competency, not only at the level of fundamental principles of building human behavior, but the ability to understand and shape complex decision-making processes at all levels and in all functions of the organization. This requires a systemic approach where human and organizational factors are at the center of the organization's attention. The human factors analysis and classification system (HFACS) concept can be used here. One of the main applications of HFACS is the classification of causal factors of incidents/accidents into the HFACS causal relationship by category. This classification or coding process is often performed on pre-existing causal factors related to events that were not originally investigated by means of HFACS [21]. Subsequently, decision-making processes are supported today primarily through multi-dimensional and multi-criteria digitalization of processes and projects in the organization. Digitalization supported by effective and efficient human management systems in the organization is becoming a new, specific platform for the development of new, different organizational and management methods and concepts. In this respect, the interdependence and coherence between human and organizational factor management processes is strongly supported by broad digital instruments. This should also include an ergonomic approach when participating in the design of the system, which consists of examining the real situation in order to look at the possible features of the system in the future [22]. In addition, in sociological terms, the principles of effective and efficient problem-solving within human and organizational factors should be used. Problem solving consists of searching the problem space of candidate states that are encoded as symbol structures generated from other states by using operators and which are tested with pattern matching methods [23].

\section{The Safety of the Technical Systems of High Reliability Organizations}

Accidents and the causes thereof remain key topics within many processes in organizations. Research efforts are strongly focused on the human factor worldwide. It is now widely accepted that accidents are a complex systemic phenomenon, and causal factors at all levels of complex sociotechnical systems and interactions [24]. The safety of technical systems results from the tight architecture of these systems. This includes safety and security aspects of technical systems. However, they consist of two different groups of functional requirements [25]. This architecture is materialized through the interdependence between the various components of the system, together with designing interface management mechanisms between them, creating a mutual, compact, integral and functional configuration of the technical system. The architecture is non-physical; it is a set of standards that allow for meaningful communication between components [26]. The principles of building safe technical systems are a compendium of knowledge for organizations in need of implementing unique solutions that determine their search for sources of competitiveness, efficiency and reliability. This triad may not only allow for survival in difficult market conditions but can also ensure the dynamic development and building of competitive potential and competitive advantage while maintaining the operational capacity equipped with safe organizational processes. However, it is important to be aware that in this context safety management systems are not a revolutionary concept or a measure that emerged spontaneously. Their appearance is closely linked to the evolution of safety thinking [27]. It is important that technical/technological and organizational changes are combined in the organization, so changes should be managed in an integrated way [28]. It is important to be aware that specific, materialized technological solutions, both those which develop safety potential and those aimed solely at strengthening security systems, are of particular importance. It is therefore crucial to create dynamic digital capabilities in organizations [29]. This should include both solutions related to the interoperability of technical systems within the framework of their technical compatibility and the safety of these systems as part of their safe integration [30]. This is where the so-called architectural compatibility is created [31]. 


\section{Process Safety Based on Digitalization and the Safety Culture of a High Reliability Organization}

Processes in high reliability organizations have a special dimension. Their input data must be sufficiently complete to ensure a safe and functional structure that generates the results of these processes, which are acceptable in terms of organizational, management, social and technological criteria. These criteria and their fulfilment, which are suitable for today's widespread socio-technological systems, fulfil the potential for optimally managed high reliability organizations. A proper architecture of a safe technical system is therefore needed. Safety-related systems usually require the provision of redundant resources in the system and have a logical method of reconfiguration in the event of failure detection. One of the problems inherent in this approach is that it may be very difficult to properly design, implement and test this reconfigurability. The dynamic architecture of the system describes it, which helps to avoid some of these difficulties. This architecture takes advantage of the fact that the processing is linked to any input data set and has a limited duration at any time. By organizing sufficient parallel redundancy, it is possible that the system is not exposed to a failure of a single process element, then recovery after error becomes very easy [32]. The architecture of the system fits into the assumptions of the systems theory, the attributes of which allow for the capture of many components. One of the crucial architectures is the system of systems architecture (SoS). This requires the simultaneous analysis of a set of individual but interconnected systems to build a communicative SoS that can provide the necessary capabilities and functionality. In general, systems can ensure a set of functions and an SoS architect must decide which systems to include in the SoS so that each possibility is ensured by at least one system. In this case, the systems are inflexible, i.e., the chosen system will bring all possible benefits to the SoS [33]. An important approach to the implementation of system integration architecture is the model called the system architecture skeleton (SAS). SAS provides a model environment that imitates the actual physical architecture of the system. Commercial equipment can be used to create SAS if it improves its distribution. SAS enables early implementation and verification of the hardware and software infrastructure and provides an environment for component verification and the incremental integration of subsystems. SAS also enables early, specific milestones, which can be formally presented to the customer. It allows for the verification of the subsystem by the observer before the whole system is implemented [34]. In this respect, it is important to link the principles of shaping and implementing complex, secure technical systems with the safety culture of high reliability organizations. Safety culture is an important component of the organizational culture of companies. It plays a particular role in high reliability entities where personnel management is related to treating them as personnel performing critical tasks to ensure the safety of the organization concerned. Safety culture is part of an organizational culture which is believed to have an impact on members' attitudes and behavior in relation to the organization's ongoing safety and hygiene activities [7]. As a result, this functional organizational culture affects all the links of the organization's functioning, mainly because of the complex, multidimensional and interdisciplinary nature of the concept of safety itself. Safety culture is "a model of fundamental assumptions, values, standards, rules, symbols and beliefs that influence the perception of challenges, opportunities and/or threats, as well as the way of feeling and thinking about safety and the related manner of behavior and action/cooperation of entities, in different ways by those individuals learned and/or articulated in the processes of a broad sense of education, including in the natural processes of internal integration and external adaptation and in other organizational processes, as well as in the process of strengthening widely defined defense, serving the reasonably harmonious development of these entities and their achievement of the most widely understood safety, for their benefit, but also for the environment" [35]. Safety culture means all material and non-material elements of a person's well-established achievements for cultivating, recovering (when lost) and raising the level of safety of certain entities. It can be considered in an individual, 
mental-spiritual dimension, social dimension and physical (material) dimension [36]. Safety culture is a phenomenon that allows people to achieve the following goals:

1. Effective control of possible hazards of an entity, resulting in an optimal level of hazards at a given location and time.

2. Recovery of the entity's safety when lost.

3. Optimizing the levels of the multisectoral development process of the safety entity, aiming at the harmony of the safety sectors in the context of the hierarchy of the entity's objectives.

4. Effective social and individual stimulation, awareness of the highest human need, self-improvement and the creation of trichotomous mental, social and material development, by supporting beliefs, motivations and attitudes strengthening individual and collective actions for the potential of autonomous defense (self-defense) of individual and group security entities [37].

Safety culture can be considered in the context of the so-called resilient organization. Different levels of this resilience can be considered, from adapting to change, through resilience, to the creation of high reliability organizations (HROs), characterized, among others, by a culture of reliability [38]. The way in which the issue of safety is perceived, appreciated and taken into account in the organization's priorities reflects the actual commitment to safety at all levels of the organization. Therefore, it is also important for railway undertakings and infrastructure managers to identify actions and behaviors that can shape a positive safety culture and to promote a culture of mutual trust, confidence and learning through their safety management system, where employees are encouraged to contribute to the development of safety by reporting dangerous incidents and providing safety-related information [39].

\section{Occupational Health and Safety in Shaping Safety Culture and the Digitalization of High Reliability Organization Processes}

The safety of personnel, particularly those performing safety-critical tasks, is the basis for building management systems based on high efficiency and reliability. A strongly built and developed safety culture should be a platform for such an approach. If it is supported by dynamically designed and implemented solutions aimed at digitalization processes, the result will be to ensure the high reliability of existing organizations in a difficult, complex and uncertain system. The system is a set of interrelated activities or entities (hardware, software, buildings, spaces, communities and people), for a common purpose, links between entities that can have a state, form, function and causality and which change and modify their state and interaction therein in given circumstances and events and which is conceptualized as existing within limits; they have inputs and outputs that can be connected in many-to-many mappings; the whole is usually larger (more useful, more powerful, functional, etc.) than the sum of the parts [40]. The interdependence between the different processes presented in a dynamic sense ensuring an acceptable safety status of the system can be indicated. The observed advantages of the proposed method are as follows:

- Complexity management through the hierarchical decomposition of the system and development of modules and interfaces using a computational tool.

- Consistency of system descriptions at different levels.

- Hierarchy, e.g., lower-level decisions should result from abstract higher-level concepts such as functions.

- The possibility of redesigning and developing multiple system architectures to facilitate the development of the product platform and the product itself and modelling of the entire product family [41].

It is also worth mentioning that today's smart products and modern digital systems are characterized by network integration, in particular the Internet of Things (IoT) and/or the Industrial Internet of Things (IIoT). Such cyber-physical systems (CPPs) increasingly take control of the basic functions of a system with added value, which are often critical. 
This means that any failures related to these functions can harm human health and life. This leads to the need to undertake functional safety analysis when designing these systems and their infrastructure which they depend on. At the same time, their integration into integrated technology networks (IT) exposes them to cybersecurity threats, i.e., malicious intrusions aimed at modifying intended, established network behavior and/or connected devices [42].

\section{Research Methodology}

Research into digital transformation in the context of shaping the safety culture of high reliability organizations covered the following issues:

- process safety;

- $\quad$ occupational health and safety;

- $\quad$ human and organizational factors-HSIs (human-system interfaces);

- $\quad$ safety management system.

Based on the proposed assessment criteria, which were identified on the basis of a broad review of the relevant literature, a research model was designed which consisted of four areas. In the first place, relevant literature in the field of scientific research was systematically reviewed and the reference titles that were most relevant to the defined areas of interest were selected. They were also the most significant in terms of solving the scientific problem. Subsequently, the proposed criteria for assessing the safety culture of high reliability organizations through digital transformation were ranked. For this purpose, the AHP method was used, which is a method of hierarchical analysis of the problem. This method is primarily used to support decision making. It was used to classify the proposed criteria in terms of their importance for shaping digital transformation processes aimed at improving the safety culture of high reliability organizations. In the next step, a comprehensive problem-solving method-the Vester method-was used to identify such factors that are most important for the effectiveness of the implementation of the principles of safety culture. It is also used to determine the force of impact of individual factors on others. In the final stage of the research under the proposed model, quantitative research was conducted among the selected population of railway undertakings who meet the definition of a high reliability organization. The designed research model is presented in Figure 1.

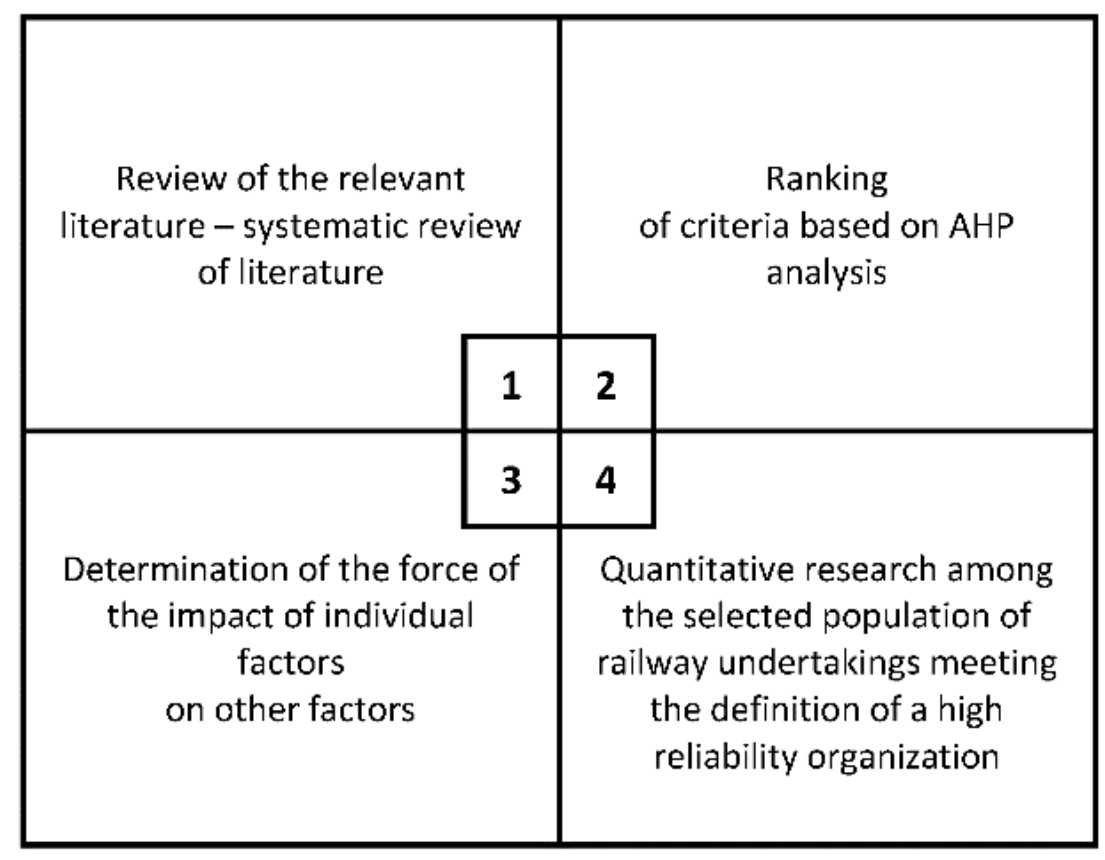

Figure 1. Adopted research model. Source: own study. 
From among railway undertakings operating on the Polish railway market, the largest railway undertakings were selected, which were assessed in terms of the impact of the digitalization criterion on the level of their safety culture. The surveyed population was $25 \%$ of 100 railway undertakings and 12 infrastructure managers operating on the Polish railway market. The result of the survey was an analysis of the responses pertaining to the extent to which the digital economy solutions used support the process of building the safety culture of the companies surveyed. Each research area had a set of questions. These questions were closed single-choice questions included in the Likert scale-from 0 to 7.

8.1. Prioritizing Key Factors in the Process of Shaping the Safety Culture of High Reliability Organizations through Digital Transformation by Means of the Analytic Hierarchy Process (AHP) Method

In 1970, American scientist T.L. Saaty developed the analytic hierarchy process (AHP) method, which is a method of hierarchical problem analysis. This method is mainly used to support decision making. In each of the four thematic areas of the safety culture mentioned above, a total of 40 factors were compared in pairs. They are compared with the level of the maturity of digital transformation processes. The above criteria were compared in pairs and their degree of fulfilment was considered. The criteria were compared in pairs using the following scale (Table 1).

Table 1. Saaty's scale used to compare criteria in pairs (own study based on [43]).

\begin{tabular}{cc}
\hline Significance Scale & Explanation \\
\hline 1 & No criterion has an advantage over the other in achieving the goal. \\
3 & Criterion A has a moderate advantage over option B. \\
5 & Criterion A has a strong advantage over option B. \\
\hline
\end{tabular}

\subsection{Determination of Weights for the Criteria Specified}

Using the Saaty scale, a matrix of pairwise comparisons for the adopted criteria was constructed. A $n \times n$ matrix was made where $n$ stands for the number of criteria. In this case $n=40$ because eight criteria were adopted. The matrix represents the predominance of one criterion over the other and the final comparison resulted in arranging the criteria in terms of final weights.

It should also be noted that there is a reversal of the assessments in the AHP method. This means that the matrix is consistent in pairs, i.e.,

$$
w_{i j} \cdot \frac{1}{w_{j i}}=1
$$

The matrix of rankings was normalized by dividing individual ratings from the criteria (in columns) by the sum of the ratings of a given criterion (sum of the column ratings) and the matrix was obtained. With a normalized matrix, the values of each row are summed up. The values obtained were divided by the number of existing criteria (i.e., number 40), resulting in weights for each criterion. The weights obtained are ranked from the highest to the lowest values, which are then shown in Table 2. 
Table 2. The level of impact of factors in Vester analysis (own study).

\begin{tabular}{|c|c|c|c|}
\hline Ranking & Group & Question & Level of Impact of Factors \\
\hline 1 & \multirow{6}{*}{$\mathrm{Y}$} & $\begin{array}{l}\text { 1. The company monitors the needs of employees and other stakeholders } \\
\text { using digital solutions }\end{array}$ & 0.0596 \\
\hline 1 & & 3. The company monitors occupational risks using digital solutions & 0.0596 \\
\hline 1 & & $\begin{array}{l}\text { 4. The company consults employees on issues of safety at work using } \\
\text { digital solutions }\end{array}$ & 0.0596 \\
\hline 1 & & $\begin{array}{l}\text { 5. The company monitors dangerous situations in safety-critical processes } \\
\text { using digital solutions }\end{array}$ & 0.0596 \\
\hline 1 & & 8. The company manages change using digital solutions & 0.0596 \\
\hline 1 & & $\begin{array}{l}\text { 9. The company ensures readiness and response to emergencies using } \\
\text { digital solutions }\end{array}$ & 0.0596 \\
\hline 7 & \multirow{7}{*}{$\mathrm{X}$} & $\begin{array}{l}\text { 9. The company applies process risk assessment methods with proposed } \\
\text { technical and organizational safeguards and risk control measures using } \\
\text { digital solutions }\end{array}$ & 0.0269 \\
\hline 8 & & $\begin{array}{l}\text { 8. The company assesses risks to safety-critical facilities using digital } \\
\text { solutions }\end{array}$ & 0.0266 \\
\hline 9 & & $\begin{array}{l}\text { 7. The company develops plans and programs to prevent failures using } \\
\text { digital solutions }\end{array}$ & 0.0263 \\
\hline 10 & & 6. The company reports on process safety using digital solutions & 0.0260 \\
\hline 11 & & $\begin{array}{l}\text { 5. The company manages information on process safety using digital } \\
\text { solutions }\end{array}$ & 0.0257 \\
\hline 12 & & 4. The company identifies the risks of digital solutions & 0.0254 \\
\hline 13 & & 3. The company monitors functional safety by means of digital solutions & 0.0250 \\
\hline 14 & \multirow{4}{*}{$\mathrm{Y}$} & $\begin{array}{l}\text { 2. The company supports leadership in the field of safety at work using } \\
\text { digital solutions }\end{array}$ & 0.0249 \\
\hline 14 & & 6. The company monitors employee behavior using digital solutions & 0.0249 \\
\hline 14 & & $\begin{array}{l}\text { 7. The company monitors communication processes in the organization } \\
\text { using digital solutions }\end{array}$ & 0.0249 \\
\hline 14 & & 10. The company monitors a culture of safe work with digital solutions & 0.0249 \\
\hline 14 & $\mathrm{Z}$ & $\begin{array}{l}\text { 8. The company ensures the expected physical and psychological capacity } \\
\text { using digital solutions }\end{array}$ & 0.0249 \\
\hline 14 & \multirow{7}{*}{$\mathrm{T}$} & $\begin{array}{l}\text { 2. The company monitors safety policy and objectives using digital } \\
\text { solutions }\end{array}$ & 0.0249 \\
\hline 14 & & $\begin{array}{l}\text { 3. The company monitors operational, organizational and technical risks } \\
\text { using digital solutions }\end{array}$ & 0.0249 \\
\hline 14 & & $\begin{array}{l}\text { 6. The company monitors criteria for risk acceptance and safety measures } \\
\text { using digital solutions }\end{array}$ & 0.0249 \\
\hline 14 & & $\begin{array}{l}\text { 7. The company monitors risks associated with operational processes } \\
\text { throughout the value chain using digital solutions }\end{array}$ & 0.0249 \\
\hline 14 & & $\begin{array}{l}\text { 8. The company monitors the performance of partners and suppliers in the } \\
\text { context of safety criteria using digital solutions }\end{array}$ & 0.0249 \\
\hline 14 & & $\begin{array}{l}\text { 9. The company manages in crisis situations, monitoring these processes } \\
\text { using digital solutions }\end{array}$ & 0.0249 \\
\hline 14 & & $\begin{array}{l}\text { 10. The company monitors the conclusions from accidents and incidents } \\
\text { using digital solutions }\end{array}$ & 0.0249 \\
\hline 26 & \multirow{3}{*}{$X$} & $\begin{array}{l}\text { 2. The company supports the process of technical risk management using } \\
\text { digital solutions; if so, to what extent }\end{array}$ & 0.0247 \\
\hline 27 & & $\begin{array}{l}\text { 1. The company monitors the system life cycle by means of digital } \\
\text { solutions; if so, to what extent }\end{array}$ & 0.0244 \\
\hline 28 & & $\begin{array}{l}\text { 10. The company manages processes related to technical rescue using } \\
\text { digital solutions }\end{array}$ & 0.0100 \\
\hline
\end{tabular}


Table 2. Cont.

\begin{tabular}{|c|c|c|c|}
\hline Ranking & Group & Question & Level of Impact of Factors \\
\hline 28 & \multirow{5}{*}{ Z } & 1. The company monitors human errors using digital solutions & 0.0100 \\
\hline 28 & & $\begin{array}{l}\text { 3. The company manages the competences of personnel performing } \\
\text { safety-critical tasks using digital solutions }\end{array}$ & 0.0100 \\
\hline 28 & & $\begin{array}{l}\text { 5. The company identifies and monitors risks associated with the } \\
\text { construction and use of equipment, tasks and working conditions using } \\
\text { digital solutions }\end{array}$ & 0.0100 \\
\hline 28 & & $\begin{array}{l}\text { 9. The company takes into account the integration of human and } \\
\text { organizational factors in the process of change management using digital } \\
\text { solutions }\end{array}$ & 0.0100 \\
\hline 28 & & $\begin{array}{l}\text { 10. The company monitors the level of human reliability using } \\
\text { digital solutions }\end{array}$ & 0.0100 \\
\hline 28 & \multirow{3}{*}{$\mathrm{T}$} & $\begin{array}{l}\text { 1. The company creates the management intentions of top managers and } \\
\text { leadership in terms of safety using digital solutions }\end{array}$ & 0.0100 \\
\hline 28 & & $\begin{array}{l}\text { 4. The company builds and monitors the awareness of human limitations } \\
\text { in the organization using digital solutions }\end{array}$ & 0.0100 \\
\hline 28 & & $\begin{array}{l}\text { 5. The company controls a professional process of conduct within the } \\
\text { processes identified in the organization using digital solutions }\end{array}$ & 0.0100 \\
\hline 37 & \multirow{4}{*}{$\mathrm{Z}$} & $\begin{array}{l}\text { 2. The company identifies and monitors interfaces-human-system } \\
\text { interfaces using digital solutions }\end{array}$ & 0.0057 \\
\hline 37 & & 4. The company monitors human limitations using digital solutions & 0.0057 \\
\hline 37 & & 6. The company monitors work ergonomics with digital solutions & 0.0057 \\
\hline 37 & & $\begin{array}{l}\text { 7. The company monitors employee fatigue and related risks using } \\
\text { digital solutions }\end{array}$ & 0.0057 \\
\hline
\end{tabular}

The following issues from all 40 analyzed issues obtained the highest weights by creating their ranking:

- The company monitors the needs of employees and other stakeholders using digital solutions.

- The company monitors occupational risks using digital solutions.

- $\quad$ The company consults employees on work safety issues using digital solutions.

- $\quad$ The company monitors dangerous situations in safety-critical processes using digital solutions.

- The company manages change using digital solutions.

- The company ensures readiness and response to emergencies using digital solutions.

All these questions are included in the group of questions " $Y$-Occupational Health and Safety" and achieved a weight value of 0.0596 . The following issues obtained the lowest weights:

- The company identifies and monitors interfaces—human-system interfaces—using digital solutions.

- The company monitors human limitations using digital solutions.

- $\quad$ The company monitors work ergonomics using digital solutions.

- $\quad$ The company monitors employee fatigue and related risks associated using digital solutions.

They received a weight of 0.0057 . These are questions from group $\mathrm{Z}$-human and organizational factors-HSIs (human-system interfaces).

8.3. Identifying Key Factors in the Process of Shaping the Safety Culture of High Reliability Organizations through Digital Transformation Using the Vester Method

The purpose of analysis using the Vester method is to identify key factors in the process of shaping the safety culture of high reliability organizations through digital transformation in order to identify such factors that are essential for the efficiency and 
success of shaping the expected safety culture. The F. Vester method of solving complex problems was used [44-49].

In the first step of this method, it is necessary to make a list of factors that have the greatest impact on a given problem. Therefore, selected factors were defined that have a significant impact on the components of the process of shaping the safety culture of a high-reliability organization through digital transformation in Supplementary Materials:

$\mathrm{X}$-process safety;

$Y$-occupational health and safety;

Z-human and organizational factors-HSIs (human-system interfaces);

$\mathrm{T}$ - safety management system.

This method is based on the assumption that not only factors affect the system tested, but also the environment of the system affects the factors examined. A direct impact is then determined between the predefined elements. To this end, a matrix is constructed that determines the force of one factor on the other on a scale of 0 to 3 where 0 means no impact and 3 is very strong impact one factor has on another. The measure of the impact of a given factor on the system is the so-called active sum (AS), determined as the sum of the points of the row corresponding to the given factor. The higher the value of the active sum, the stronger the impact on the system and at the same time it means that the factor is more susceptible to external impacts. The measure of the system impact on a given factor is called the passive sum (PS). This is the sum of the points in the column for a given factor. The higher the value of the passive sum, the more the system affects a given factor. For these sums and for each factor, two subsets have been created:

- the first contains factors with low impact (below the arithmetic mean of the sum),

- the second set includes factors that are more susceptible to the system.

Table 3 shows active and passive factors.

Table 3. Profile of the factors constituting the active sum and the passive sum (own study).

\begin{tabular}{|c|c|c|c|c|c|c|c|}
\hline \multirow{4}{*}{ No. } & \multirow{4}{*}{ 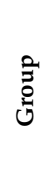 } & \multirow{4}{*}{ Factors } & \multicolumn{2}{|c|}{ Active Sum } & \multicolumn{3}{|c|}{ Passive Sum } \\
\hline & & & Low & High & Low & & High \\
\hline & & & \multicolumn{2}{|c|}{ Impact } & \multicolumn{3}{|c|}{ Impact } \\
\hline & & & 15 & 30 & 0 & 15 & 30 \\
\hline 1 & \multirow{10}{*}{$\mathrm{X}$} & 1. The company monitors the system life cycle using digital solutions; if so, to what extent. & 11 & & 8 & & \\
\hline 2 & & 2. The company supports the process of technical risk management using digital solutions. & 11 & & 8 & & \\
\hline 3 & & 3. The company monitors functional safety using digital solutions. & 11 & & $\begin{array}{l}0 \\
8\end{array}$ & & \\
\hline 4 & & 4. The company identifies threats to digital solutions. & 11 & & 8 & & \\
\hline 5 & & 5. The company manages information on process safety using digital solutions. & 11 & & 8 & & \\
\hline 6 & & 6. The company reports on process safety using digital solutions. & 11 & & 8 & & \\
\hline 7 & & 7. The company develops plans and programs to prevent failures using digital solutions. & 11 & & 8 & & \\
\hline 8 & & 8. The company assesses risks to safety-critical facilities using digital solutions. & 11 & & 8 & & \\
\hline 9 & & $\begin{array}{l}\text { 9. The company applies process risk assessment methods with proposed technical and organizational } \\
\text { safeguards and risk control measures using digital solutions. }\end{array}$ & 11 & & 8 & & \\
\hline 10 & & 10. The company manages processes related to technical rescue using digital solutions. & 0 & & & & 27 \\
\hline 11 & \multirow{10}{*}{$\mathrm{Y}$} & 1. The company monitors the needs of employees and other stakeholders using digital solutions. & & 17 & 5 & & \\
\hline 12 & & 2. The company supports leadership in the field of safety at work using digital solutions. & 3 & & 21 & & \\
\hline 13 & & 3. The company monitors occupational risks using digital solutions. & & 17 & 5 & & \\
\hline 14 & & 4. The company consults employees on work safety issues using digital solutions. & & 17 & 5 & & \\
\hline 15 & & 5. The company monitors dangerous situations in safety-critical processes using digital solutions. & & 17 & 5 & & \\
\hline 16 & & 6. The company monitors the behavior of employees using digital solutions. & 3 & & & & 21 \\
\hline 17 & & 7. The company monitors communication processes in the organization using digital solutions. & 3 & & & & 21 \\
\hline 18 & & 8. The company manages change using digital solutions. & & 17 & 5 & & \\
\hline 19 & & 9. The company ensures readiness and response to emergencies using digital solutions. & & 17 & 5 & & \\
\hline 20 & & 10. The company monitors a culture of safe work using digital solutions. & 3 & & & & 21 \\
\hline 21 & \multirow{8}{*}{$\mathrm{Z}$} & 1. The company monitors human errors using digital solutions. & & 16 & 7 & & \\
\hline 22 & & 2. The company identifies and monitors interfaces-human-system interfaces using digital solutions. & 3 & & & & 21 \\
\hline 23 & & $\begin{array}{l}\text { 3. The company manages the competences of personnel performing safety critical tasks using digital } \\
\text { solutions. }\end{array}$ & & 16 & 7 & & \\
\hline 24 & & 4. The company monitors human limitations using digital solutions. & 3 & & & & 21 \\
\hline 25 & & $\begin{array}{l}\text { 5. The company identifies and monitors risks associated with the construction and use of equipment, } \\
\text { tasks and working conditions using digital solutions. }\end{array}$ & & 16 & 7 & & \\
\hline 26 & & 6. The company monitors work ergonomics using digital solutions. & 3 & & & & 21 \\
\hline 27 & & 7. The company monitors employee fatigue and related risks using digital solutions. & 3 & & & & 21 \\
\hline 28 & & 8. The company ensures the expected physical and psychological capacity using digital solutions. & & 27 & 0 & & \\
\hline
\end{tabular}


Table 3. Cont.

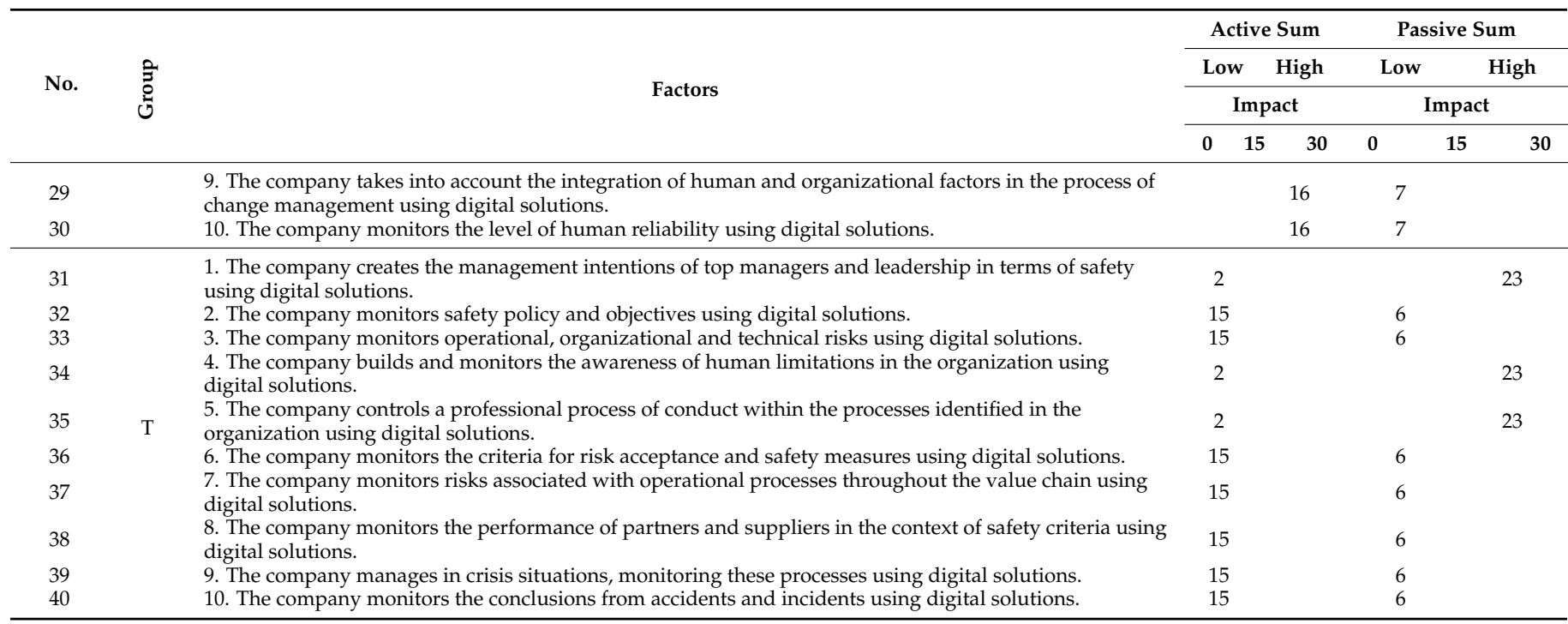

The so-called quotient and product are used to determine the interdependence between various factors and the system. The quotient is a measure of the relationship between the force of impact of a factor on the system and its susceptibility to the system and is determined for each factor by multiplying the active sum determined for a given factor by 100 and dividing the result by the passive sum of the factor. The product is a measure of the importance of the factor in the system. The product of a given factor is the multiplication of its active sum by the passive sum of this factor. In the case of a quotient greater than 100, the tested factor affects the system with more force than the system affects it. On the other hand, the high value of the product of a given factor offers an indication of its importance in the system and vice versa. After ordering the increasing product values and dividing 40 factors into three groups (by the number of factors), a percentage of the products was created. Table 4 shows the results of the quotient and product calculations for factors.

Table 4. Calculation of the quotient and product for factors (own study).

\begin{tabular}{|c|c|c|c|c|c|c|c|}
\hline \multirow{3}{*}{ No. } & \multirow{3}{*}{ 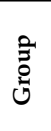 } & \multirow{3}{*}{ Factors } & \multicolumn{2}{|c|}{ Quotient } & \multirow{2}{*}{\multicolumn{3}{|c|}{ Product }} \\
\hline & & & \multirow{2}{*}{$\begin{array}{c}\text { Low } \\
<100\end{array}$} & \multirow{2}{*}{$\begin{array}{l}\text { High } \\
\geq 100\end{array}$} & & & \\
\hline & & & & & Low $33 \%$ & $33 \%$ & High $33 \%$ \\
\hline 1 & \multirow{10}{*}{$\mathrm{x}$} & 1. The company monitors the system life cycle using digital solutions. & & 138 & & & 88 \\
\hline 2 & & $\begin{array}{l}\text { 2. The company supports the process of technical risk management using } \\
\text { digital solutions. }\end{array}$ & & 138 & & & 88 \\
\hline 3 & & 3. The company monitors functional safety by means of digital solutions. & & 138 & & & 88 \\
\hline 4 & & 4. The company identifies risks using digital solutions. & & 138 & & & 88 \\
\hline 5 & & 5. The company manages information on process safety using digital solutions. & & 138 & & & 88 \\
\hline 6 & & 6 . The company reports on process safety using digital solutions. & & 138 & & & 88 \\
\hline 7 & & 7. The company develops plans and programs to prevent failures using digital solutions. & & 138 & & & 88 \\
\hline 8 & & 8. The company assesses risks to safety-critical facilities using digital solutions. & & 138 & & & 88 \\
\hline 9 & & $\begin{array}{l}\text { 9. The company uses process risk assessment methods with proposed technical and } \\
\text { organizational safeguards and risk control measures using digital solutions. }\end{array}$ & & 138 & & & 88 \\
\hline 10 & & 10. The company manages processes related to technical rescue using digital solutions. & 0 & & 0 & & \\
\hline 11 & \multirow{10}{*}{ Y } & $\begin{array}{l}\text { 1. The company monitors the needs of employees and other stakeholders using } \\
\text { digital solutions. }\end{array}$ & & 340 & & & 85 \\
\hline 12 & & 2. The company supports leadership in the field of safety at work using digital solutions. & 14 & & & 63 & \\
\hline 13 & & 3. The company monitors occupational risks using digital solutions. & & 340 & & & 85 \\
\hline 14 & & 4. The company consults employees on work safety issues using digital solutions. & & 340 & & & 85 \\
\hline 15 & & $\begin{array}{l}\text { 5. The company monitors dangerous situations in safety-critical processes using } \\
\text { digital solutions. }\end{array}$ & & 340 & & & 85 \\
\hline 16 & & 6. The company monitors the behavior of employees using digital solutions. & 14 & & & 63 & \\
\hline 17 & & $\begin{array}{l}\text { 7. The company monitors communication processes in the organization using } \\
\text { digital solutions. }\end{array}$ & 14 & & & 63 & \\
\hline 18 & & 8. The company manages change using digital solutions. & & 340 & & & 85 \\
\hline 19 & & 9. The company ensures readiness and response to emergencies using digital solutions. & & 340 & & & 85 \\
\hline 20 & & 10. The company monitors a culture of safe work using digital solutions. & 14 & & & 63 & \\
\hline
\end{tabular}


Table 4. Cont

\begin{tabular}{|c|c|c|c|c|c|c|c|}
\hline \multirow{3}{*}{ No. } & \multirow{3}{*}{ 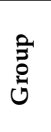 } & \multirow{3}{*}{ Factors } & \multicolumn{2}{|c|}{ Quotient } & \multirow{2}{*}{\multicolumn{3}{|c|}{ Product }} \\
\hline & & & \multirow{2}{*}{$\begin{array}{l}\text { Low } \\
<100\end{array}$} & \multirow{2}{*}{$\begin{array}{l}\text { High } \\
\geq 100\end{array}$} & & & \\
\hline & & & & & Low $33 \%$ & $33 \%$ & High $33 \%$ \\
\hline 21 & & 1. The company monitors human errors using digital solutions. & & 229 & & & 112 \\
\hline 22 & & $\begin{array}{l}\text { 2. The company identifies and monitors interfaces-human-system interfaces using } \\
\text { digital solutions. }\end{array}$ & 14 & & & 63 & \\
\hline 23 & & $\begin{array}{l}\text { 3. The company manages the competences of personnel performing safety-critical tasks } \\
\text { using digital solutions. }\end{array}$ & & 229 & & & 112 \\
\hline 24 & & 4. The company monitors human limitations using digital solutions. & 14 & & & 63 & \\
\hline 25 & Z & $\begin{array}{l}\text { 5. The company identifies and monitors risks associated with the construction and use of } \\
\text { equipment, tasks and working conditions using digital solutions. }\end{array}$ & & 229 & & & 112 \\
\hline 26 & & 6. The company monitors work ergonomics using digital solutions. & 14 & & & 63 & \\
\hline 27 & & 7. The company monitors employee fatigue and related risks using digital solutions. & 14 & & & 63 & \\
\hline 28 & & $\begin{array}{l}\text { 8. The company ensures the expected physical and psychological capacity using } \\
\text { digital solutions. }\end{array}$ & - & - & 0 & & \\
\hline 29 & & $\begin{array}{l}\text { 9. The company takes into account the integration of human and organizational factors in } \\
\text { the process of change management using digital solutions. }\end{array}$ & & 229 & & & 112 \\
\hline 30 & & 10. The company monitors the level of human reliability using digital solutions. & & 229 & & & 112 \\
\hline 31 & & $\begin{array}{l}\text { 1. The company creates the management intentions of top managers and leadership in } \\
\text { terms of safety using digital solutions. }\end{array}$ & 9 & & & 46 & \\
\hline 32 & & 2. The company monitors safety policy and safety objectives using digital solutions. & & 250 & & & 90 \\
\hline 33 & & $\begin{array}{l}\text { 3. The company monitors operational, organizational and technical risks using } \\
\text { digital solutions. }\end{array}$ & & 250 & & & 90 \\
\hline 34 & & $\begin{array}{l}\text { 4. The company builds and monitors the awareness of human limitations in the } \\
\text { organization using digital solutions. }\end{array}$ & 9 & & & 46 & \\
\hline 35 & & $\begin{array}{l}\text { 5. The company controls a professional process of conduct within the processes identified } \\
\text { in the organization using digital solutions. }\end{array}$ & 9 & & & 46 & \\
\hline 36 & $\mathrm{~T}$ & $\begin{array}{l}\text { 6. The company monitors the criteria for risk acceptance and safety measures using } \\
\text { digital solutions. }\end{array}$ & & 250 & & & 90 \\
\hline 37 & & $\begin{array}{l}\text { 7. The company monitors risks associated with operational processes throughout the } \\
\text { value chain using digital solutions. }\end{array}$ & & 250 & & & 90 \\
\hline 38 & & $\begin{array}{l}\text { 8. The company monitors the performance of partners and suppliers in the context of } \\
\text { safety criteria using digital solutions. }\end{array}$ & & 250 & & & 90 \\
\hline 39 & & $\begin{array}{l}\text { 9. The company manages in crisis situations, monitoring these processes using } \\
\text { digital solutions. }\end{array}$ & & 250 & & & 90 \\
\hline 40 & & $\begin{array}{l}\text { 10. The company monitors the conclusions from accidents and incidents using } \\
\text { digital solutions. }\end{array}$ & & 250 & & & 90 \\
\hline
\end{tabular}

The boundaries between these ranges of factor division into those with a quotient greater than 100 and less than 100 points, and those with the highest, average or smallest product in the graph are, in the first case, a line starting at the beginning of the coordinate system and symmetrically dividing the coordinate system, and in the second case a curve based on points determined by factors with the largest and lowest passive sums. In this example, only two factors are at the boundary of the product line. These factors have the greatest impact on the process of shaping the safety culture of high reliability organizations, and they include the following:

- $\quad$ The company ensures the expected physical and psychological capacity using digital solutions;

- The company manages processes related to technical rescue using digital solutions.

On the basis of the graph (Figure 2), a visual presentation of the division into factors is created, which is indicated in the table below (Table 5). They include no critical factors.

Twelve factors are active factors, 16 are buffering factors and 12 are passive factors. This means that a large proportion of the factors studied (which are active factors) have an impact on the digital transformation in shaping the HRO safety culture. On the other hand, the buffering factors are characterized by a slight impact on digital transformation and limited flexibility in shaping the HRO safety culture. Passive factors have limited impact on digital transformation in shaping the HRO safety culture, while they themselves are heavily influenced by safety culture. 


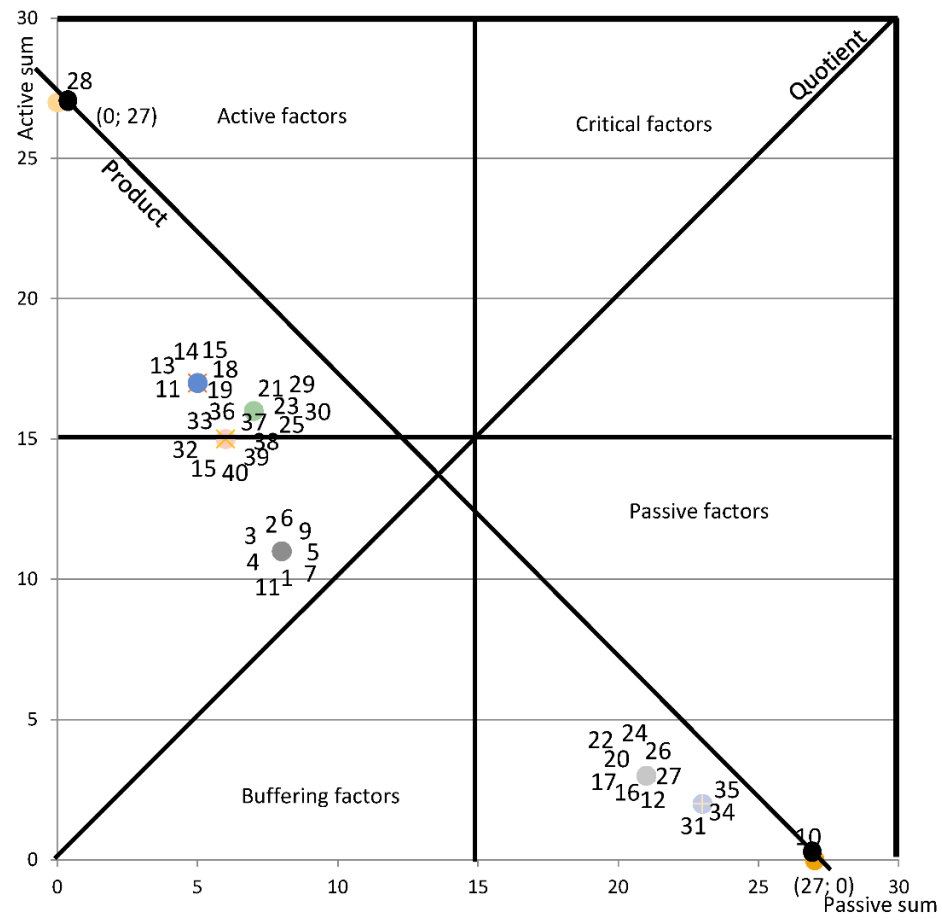

Figure 2. A matrix of factors. Source: own study.

Table 5. Groups of factors in Vester analysis (own study).

\begin{tabular}{|c|c|c|c|}
\hline No. & Group & Factors & Factors \\
\hline 28 & $\mathrm{Z}$ & $\begin{array}{l}\text { 8. The company ensures the expected physical and psychological capacity using } \\
\text { digital solutions. }\end{array}$ & \multirow{7}{*}{ Active } \\
\hline 11 & \multirow{6}{*}{ Y } & $\begin{array}{l}\text { 1. The company monitors the needs of employees and other stakeholders using } \\
\text { digital solutions. }\end{array}$ & \\
\hline 13 & & 3. The company monitors occupational risks using digital solutions. & \\
\hline 14 & & 4. The company consults employees on work safety issues using digital solutions. & \\
\hline 15 & & $\begin{array}{l}\text { 5. The company monitors dangerous situations in safety-critical processes using } \\
\text { digital solutions. }\end{array}$ & \\
\hline 18 & & 8. The company manages change using digital solutions. & \\
\hline 19 & & 9. The company ensures readiness and response to emergencies using digital solutions. & \\
\hline 32 & \multirow{7}{*}{$\mathrm{T}$} & 2. The company monitors safety policy and safety objectives using digital solutions. & \multirow{7}{*}{ Buffering } \\
\hline 33 & & 3. The company monitors operational, organizational and technical risks using digital solutions. & \\
\hline 36 & & $\begin{array}{l}\text { 6. The company monitors the criteria for risk acceptance and safety measures using } \\
\text { digital solutions. }\end{array}$ & \\
\hline 37 & & $\begin{array}{l}\text { 7. The company monitors risks associated with operational processes throughout the value } \\
\text { chain using digital solutions. }\end{array}$ & \\
\hline 38 & & $\begin{array}{l}\text { 8. The company monitors the performance of partners and suppliers in the context of safety } \\
\text { criteria using digital solutions. }\end{array}$ & \\
\hline 39 & & 9. The company manages in crisis situations, monitoring these processes using digital solutions. & \\
\hline 40 & & 10. The company monitors the conclusions from accidents and incidents using digital solutions. & \\
\hline 21 & \multirow{5}{*}{ Z } & 1. The company monitors human errors using digital solutions. & \multirow{5}{*}{ Active } \\
\hline 23 & & $\begin{array}{l}\text { 3. The company manages the competences of personnel performing safety-critical tasks using } \\
\text { digital solutions. }\end{array}$ & \\
\hline 25 & & $\begin{array}{l}\text { 5. The company identifies and monitors risks associated with the construction and use of } \\
\text { equipment, tasks and working conditions using digital solutions. }\end{array}$ & \\
\hline 29 & & $\begin{array}{l}\text { 9. The company takes into account the integration of human and organizational factors in the } \\
\text { process of managing change using digital solutions. }\end{array}$ & \\
\hline 30 & & 10. The company monitors the level of human reliability using digital solutions. & \\
\hline
\end{tabular}


Table 5. Cont.

\begin{tabular}{|c|c|c|c|}
\hline No. & Group & Factors & Factors \\
\hline 1 & \multirow{9}{*}{$x$} & 1. The company monitors the system life cycle with digital solutions. & \multirow{9}{*}{ Buffering } \\
\hline 2 & & 2. The company supports the process of technical risk management using digital solutions. & \\
\hline 3 & & 3. The company monitors functional safety using digital solutions. & \\
\hline 4 & & 4. The company identifies threats to digital solutions. & \\
\hline 5 & & 5. The company manages information on process safety using digital solutions. & \\
\hline 6 & & 6. The company reports on process safety using digital solutions. & \\
\hline 7 & & 7. The company develops plans and programs to prevent failures using digital solutions. & \\
\hline 8 & & 8. The company assesses the risks to safety-critical facilities using digital solutions. & \\
\hline 9 & & $\begin{array}{l}\text { 9. The company uses process risk assessment methods with proposed technical and } \\
\text { organizational safeguards and risk control measures using digital solutions. }\end{array}$ & \\
\hline 12 & \multirow{4}{*}{$\mathrm{Y}$} & 2. The company supports leadership in the field of safety at work using digital solutions. & \multirow{12}{*}{ Passive } \\
\hline 16 & & 6. The company monitors the behavior of employees using digital solutions. & \\
\hline 17 & & 7. The company monitors communication processes in the organization using digital solutions. & \\
\hline 20 & & 10. The company monitors a culture of safe work using digital solutions. & \\
\hline 22 & \multirow{4}{*}{ Z } & $\begin{array}{l}\text { 2. The company identifies and monitors interfaces-human-system interfaces using digital } \\
\text { solutions. }\end{array}$ & \\
\hline 24 & & 4. The company monitors human limitations using digital solutions. & \\
\hline 26 & & 6. The company monitors work ergonomics using digital solutions. & \\
\hline 27 & & 7. The company monitors employee fatigue and related risks using digital solutions. & \\
\hline 31 & \multirow{3}{*}{$\mathrm{T}$} & $\begin{array}{l}\text { 1. The company creates the management intentions of top managers and leadership in terms of } \\
\text { safety using digital solutions. }\end{array}$ & \\
\hline 34 & & $\begin{array}{l}\text { 4. The company builds and monitors the awareness of human limitations in the organization } \\
\text { using digital solutions. }\end{array}$ & \\
\hline 35 & & $\begin{array}{l}\text { 5. The company controls a professional process of conduct within the processes identified in } \\
\text { the organization using digital solutions. }\end{array}$ & \\
\hline 10 & $X$ & 10. The company manages processes related to technical rescue using digital solutions. & \\
\hline
\end{tabular}

Source: own study.

\subsection{Quantitative Research-Surveys}

The average results obtained in terms of the role of digital transformation in shaping the HRO security culture ranged between 0.75 and 1.50 (Figure 3). The highest values were obtained for the group "Occupational health and safety"- between 1.25 and 1.50. The highest values of 1.5 were for the following:

- $\quad$ the company monitors the needs of employees and other stakeholders using digital solutions,

- the company monitors occupational risks using digital solutions,

- the company consults employees on work safety issues using digital solutions,

- $\quad$ the company monitors dangerous situations in safety-critical processes using digital solutions,

- the company manages change using digital solutions,

- $\quad$ the company ensures readiness and response to emergencies using digital solutions.

On the other hand, the lowest values were obtained by the group of questions from the category "Human and organizational factors"-between 0.75 and 1.25. The lowest values were obtained for the following issues:

- the company identifies and monitors interfaces—human-system interfaces—using digital solutions,

- the company monitors human limitations using digital solutions,

- the company monitors work ergonomics using digital solutions,

- the company monitors employee fatigue and related risks using digital solutions.

This means that the average of all survey results obtained was 1.18 of a possible 7 . Therefore, the companies examined are characterized by a very low level of development of a safety culture of high reliability organizations through digital transformation. Companies 
use simple solutions in the field of the digital economy-basic process-supporting software, e.g., Excel (corresponding to 1 in the survey). At the same time, however, the results reveal that to a certain extent, companies take into account the monitoring of the issues examined, i.e., process safety, occupational health and safety, human and organizational factors-HSIs (human-system interfaces) and the safety management system. However, the average value of 0.75 points to responses where the company does not use any digital economy solutions.

The accumulation of results around the value of 1 (Figure 4) shows that a long road remains to the full process of shaping the safety culture of high reliability organizations through digital transformation, and companies should continue working to improve their safety culture.

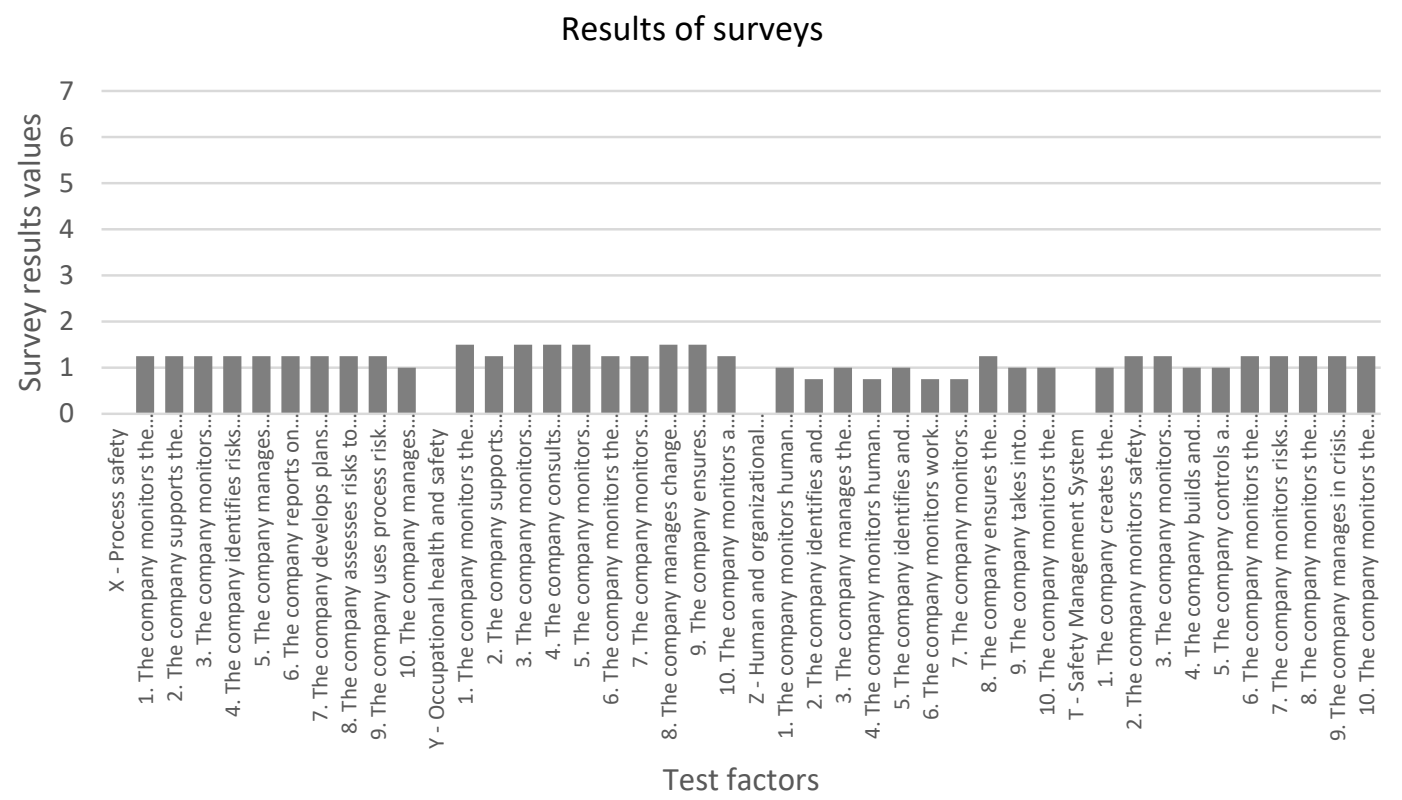

Figure 3. Results of the surveys. Source: own study.

Level of the process of shaping the safety culture of high reliability organizations through digital transformation

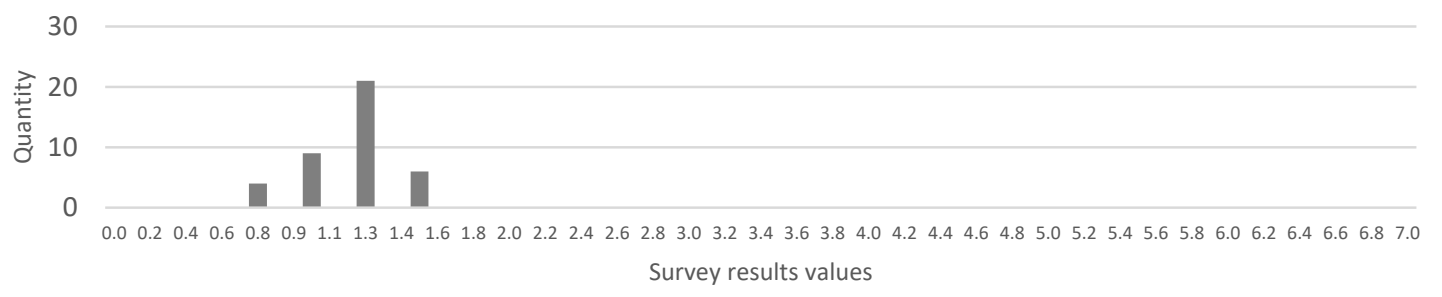

Figure 4. Distribution of survey results. Source: own study.

\section{Conclusions}

The results of research into shaping the safety culture of high reliability organizations through digital transformation clearly show that this is one of the areas of research that are in the early stages of development. The digital transformation slightly influences the development of safety culture. This is not due to the lack of a strong relationship between these issues, but the low level of implementation of digital solutions in terms of safety issues in general. Safety culture affects numerous areas of high reliability organizations. These areas belong to different categories and areas of operation of these organizations. A broad, holistic view of the processes of shaping the safety culture of a high reliability organization requires a search for the possibility of applying digital transformation processes in each of the many areas of operation of such organizations and, subsequently, assessing the maturity of these solutions and their impact on this safety culture. A broad and systematic literature 
review, consistent with the accepted issues responsible for building safety culture, showed that this topic is interdisciplinary and the authors of works represent different points of view on the subject presented. The ranking of individual issues responsible for building safety culture using the AHP method showed that the most digitalized elements concern occupational safety and health issues, human and organizational factors and process safety related to the operation of socio-technological systems. The results of Vester analysis used to identify such factors that are essential to the effectiveness of the process of shaping the expected safety culture by demonstrating the relationship between the variables forming this culture showed that there are no critical factors. This means that the elements which have a very important impact on other elements were not exposed. Most aspects studied by means of this method have similar mutual relationships, which means that according to its essence, safety culture is a set of relatively consistent factors which, together, without demonstrating particularly important elements, should only build a positive safety culture of high reliability organizations. Quantitative research on a defined research sample of companies active in the rail transport sector recognized as representative of high reliability organizations showed that companies are currently applying basic solutions in the field of the digital economy. Their maturity in this area is still low. At the same time, it is demonstrated that companies take into account, to some extent, the monitoring of the issues examined, i.e., process safety, occupational health and safety, human and organizational factors-HSIs (human-system interfaces) and the safety management system. In these areas, they attempt to apply solutions to implement the digital transformation process in the context of determinants responsible for safety culture.

Based on scientific research related to assessing the impact of the digital transformation process on shaping the HRO safety culture, the following assumptions for the theory in this respect have been identified:

1. Digital transformation processes are taking place in many sectors of the economy and include specific organizations such as the high reliability organization.

2. The ranking of criteria describing the safety culture of a high reliability organization in the context of the digital transformation showed that the main priorities are focused on monitoring the needs of employees and other stakeholders, monitoring occupational risks, consulting workers on occupational safety issues and monitoring hazardous situations in safety-critical processes.

3. Based on the literature review criteria, Vester analysis showed that out of 40, 12 factors are active factors, 16 are buffering factors and 12 are passive factors. This means that most of the important factors of safety culture are not affected by digital transformation processes.

4. Quantitative research among the selected companies showed that digital transformation processes currently only support the change and development of the HRO security culture to a very limited extent.

On the basis of observations of the technological development in the area of the safety management of high reliability organizations, the role of digital transformation processes will grow, indicating the need to re-examine and study this issue in the future.

The limitations to be identified in the first place are the conditions for the specific functioning of a high reliability organization, which is based on the assumptions of the socio-technical system, where digital transformation processes should be built up in technological processes. Particularly in terms of safety culture, this issue is holistic and requires the implementation of comprehensive solutions rather than the dedicated tools of the digital economy related to specific areas. Therefore, a noticeable limitation is a wide range of topics pertaining to the issue of safety culture. Many processes are still conducted in an analogous way, as demonstrated in the conclusions confirming the low impact of digital transformation processes on the development of safety culture. This relationship will certainly change in the future. The above statement now points to key limitations in this regard. 
To sum up the scientific discussion, it is important to refer to the contribution made by the article and the results obtained to scientific knowledge in management and quality sciences.

This reference has a multifaceted dimension due to the interdisciplinary nature of the scientific problem posed. This applies in particular to the place and role of shaping safety culture in high reliability organizations and the degree of the use of digital transformation solutions to enhance the safety culture of high reliability organizations. In the first case, the impact on the development of management and quality science concerns, inter alia, the cause-and-effect relationship between raising the level of safety culture and eliminating the possibility of disasters, accidents and incidents through mechanisms for shaping it. In the second case, there is a relationship between management methods and concepts used to shape safety culture and digitalization in the field of technology, and processes and project control that increase the reliability and safety of dynamic, interactive socio-technological systems. The resulting platform and the determinant of improving the management mechanisms of high reliability organizations in this case is the constructive comparison of technological and social factors. It materializes in the form of socio-technological impact generated for the benefit of different stakeholder groups living in the ecosystem of real relationships and the digital ecosystem of virtual connections. This creates a further basis for the development of management and quality sciences and opens wider cognitive perspectives for the multidimensional exploration of this scientific problem.

It is important to hold a discussion on the relationship between the foundations of the theory related to the scientific problem raised and the research results. Undoubtedly, the digital transformation and the complex digitalization of processes and projects have opened a wide range of opportunities to improve safety and reliability. This applies both to the scientific discussion and to the interdisciplinary application of management and technological solutions. The construction of complex technical systems requires an appropriate selection and comprehensible logic of the theory used, in this case, inter alia, the theory concerning the principles of safe integration, technical compatibility, a configuration approach along with the definition of the interfaces taking place and criticality analyses in technical systems. With regard to management principles, this materializes in the form of a proper understanding of the safety culture, safety management mechanisms, the proper understanding of the specificity of the functioning of high reliability organizations and the place and the role of the human and organizational factors in management processes, among other things. This theoretical approach clearly paves the way for the analysis and synthesis of the results of scientific research, which, by means of this platform, open transparent space for further scientific research and translating it into the results of specific entities embedded in the economy.

It should be noted that this topic, as well as the scientific problem of shaping the safety culture of high reliability organizations through digital transformation, is relatively new and cognitively interesting. It is important in both theoretical and practical terms due to its strong applicability and embedment in the realities of modern expectations for the economy. However, there is very little research in this area. It refers to different approaches but is often partial and fragmented. This article uses a holistic approach relevant to complex systems in order to develop optimal mechanisms for shaping safety culture through digital transformation. It is also worth noting that there is little research involving both social and technological factors in the context of high reliability organizations using modern digital solutions. It can therefore be a visible space and a broad perspective for the further development of this important issue. The authors believe that this topic is vitally important to an understanding of the processes of digital transformation in the specific context of the HRO safety culture. The content of the article is consistent with the objectives, orientation and readership of the scientific journal (Energies).

Supplementary Materials: The following are available online at https:/ / www.mdpi.com/article / 10.3390/en14164721/s1. 
Author Contributions: Conceptualization, M.J.; formal analysis, A.J. and M.J.; investigation, A.J.; methodology, M.J.; resources, A.J.; supervision, A.J. All authors have read and agreed to the published version of the manuscript.

Funding: This research received no external funding.

Institutional Review Board Statement: Not applicable.

Informed Consent Statement: Not applicable.

Data Availability Statement: Not applicable.

Conflicts of Interest: The authors declare no conflict of interest.

\section{References}

1. Roberts, K.H. Some characteristics of high-reliability organizations. Organ. Sci. 1990, 1, 160-177. [CrossRef]

2. Hopkins, A. WP 51-The Problem of Defining High Reliability Organisations; National Research Centre for OHS Regulation: Canberra, Australia, 2007.

3. Baker, D.; Day, R.; Salas, E. Teamwork as an essential component of high-reliability organizations. Health Serv. Res. 2006, 41, 1576-1598. [CrossRef]

4. Hutchison, D.; Sterbenz, J.P.G. Architecture and design for resilient networked systems. Comput. Commun. 2018, 131, 13-21. [CrossRef]

5. Bergström, J.; van Winsen, R.; Henriqson, E. On the rationale of resilience in the domain of safety: A literature review. Reliab. Eng. Syst. Saf. 2015, 141, 131-141. [CrossRef]

6. Christianson, M.K.; Sutcliffe, K.M.; Miller, M.A.; Iwashyna, T.J. Becoming a high reliability organization. Crit. Care 2011, 15, 314. [CrossRef] [PubMed]

7. Cooper, M.D. Towards a model of safety culture. Saf. Sci. 2000, 36, 111-136. [CrossRef]

8. Reason, J. Human error: Models and management. BMJ 2000, 320, 768-770. [CrossRef]

9. Hersh, M.A. Whistleblowers-Heroes or traitors?: Individual and collective responsibility for ethical behaviour. Annu. Rev. Control 2002, 26, 243-262. [CrossRef]

10. Frankel, A.S.; Leonard, M.W.; Denham, C.R. Fair and Just Culture, Team Behavior, and Leadership Engagement: The Tools to Achieve High Reliability. Health Serv. Res. 2006, 41, 1690-1709. [CrossRef]

11. Khan, F.; Amyotte, P.; Adedigba, S. Process safety concerns in process system digitalization. Educ. Chem. Eng. 2021, 34, 33-46. [CrossRef]

12. Zaouia, F.; Souissi, N. Roadmap for digital transformation: A literature review. Procedia Comput. Sci. 2020, 175, 621-628. [CrossRef]

13. Parida, V.; Sjödin, D.; Reim, W. Reviewing Literature on Digitalization, Business Model Innovation, and Sustainable Industry: Past Achievements and Future Promises. Sustainability 2019, 11, 391. [CrossRef]

14. Fabian, N.; Haenlein, M. Digital transformation: A multidisciplinary reflection and research agenda. J. Bus. Res. 2021, 122, 889-901.

15. Teece, D.J. Profiting from innovation in the digital economy: Enabling technologies, standards, and licensing models in the wireless world. Res. Policy 2018, 47, 1367-1387. [CrossRef]

16. Bakhtadze, N.; Suleykin, A. Industrial digital ecosystems: Predictive models and architecture development issues. Annu. Rev. Control 2020, in press.

17. Śliwiński, M.; Piesik, E.; Piesik, J. Integrated functional safety and cyber security analysis. IFAC Pap. 2018, 51, 1263-1270. [CrossRef]

18. Vygotsky, L.S. Consciousness as a problem in the psychology of behavior. J. Russ. East Eur. Psychol. 1979, 17, 3-35.

19. Górska, E. Jakość i Ergonomia-Bezpiecznie i wygodnie. Probl. Jakości. 2015, 12, 37.

20. Mittelstaedt, R.E., Jr. Jak Uniknąć Pomyłek, Które Mogą Zniszczyć Twoją Organizację; Wydawnictwo Helion: Gliwice, Poland, 2006.

21. Ergai, A.; Cohen, T.; Sharp, J.; Wiegmann, D.; Gramopadhye, A.; Shappell, S. Assessment of the Human Factors Analysis and Classification System (HFACS): Intra-rater and inter-rater reliability. Saf. Sci. 2016, 82, 393-398. [CrossRef]

22. De la Garza, C.; Weill-Fassina, A.; Kaplan, M. Integrating human factors in freight interoperability safety design. Cogn. Technol. Work 2008, 10, 61-68. [CrossRef]

23. Langley, P.; Trivedi, N. Elaborations on a Theory of Human Problem Solving. Adv. Cogn. Syst. 2013, 3, 1-12.

24. Salmon, P.M.; Cornelissen, M.; Trotter, M.J. Systems-based accident analysis methods: A comparison of Accimap, HFACS, and STAMP. Saf. Sci. 2012, 50, 1158-1170. [CrossRef]

25. Piesik, E.; Śliwiński, M.; Barnert, T. Determining and verifying the safety integrity level of the safety instrumented systems with the uncertainty and security aspects. Reliab. Eng. Syst. Saf. 2016, 152, 259-272. [CrossRef]

26. Maier, M.W. Architecting Principles for Systems-of-Systems. J. Int. Counc. Syst. Eng. 1999, 1, 267-284.

27. Bieder, C. Safety science: A situated science An exploration through the lens of Safety Management Systems. Saf. Sci. 2021, 135, 105063. [CrossRef] 
28. Gerbec, M. Safety change management-A new method for integrated management of organizational and technical changes. Saf. Sci. 2017, 100, 225-234. [CrossRef]

29. Annarelli, A.; Battistella, C.; Nonino, F.; Parida, V.; Pessot, E. Literature review on digitalization capabilities: Co-citation analysis of antecedents, conceptualization and consequences. Technol. Forecast. Soc. 2021, 166, 120635. [CrossRef]

30. Panetto, H.; Cecil, J. Information systems for enterprise integration, interoperability and networking: Theory and applications Enterp. Inform. Syst. 2013, 7, 1-6. [CrossRef]

31. Land, R.; Crnkovic, I. Software systems in-house integration: Architecture, process practices, and strategy selection. Inform. Softw. Technol. 2007, 49, 419-444. [CrossRef]

32. Quirk, W.J. A Dynamic System Architecture For Safety Related Systems. IFAC Proc. Vol. 1985, 18, 7-12. [CrossRef]

33. Konur, D.; Farhangi, H.; Dagli, C.H. On the Flexibility of Systems in System of Systems Architecting. Procedia Comput. Sci. 2014, 36, 65-71. [CrossRef]

34. Houser, P.B. Best Practices for Systems Integration; Northrop Grumman Systems Corporation: Huntsville, AL, USA, 2011.

35. Cieślarczyk, M. Kultura Bezpieczeństwa i Obronności; Wydawnictwo Akademii Podlaskiej: Siedlce, Poland, 2010 ; p. 210.

36. Piwowarski, J. Trzy filary kultury bezpieczeństwa. Secur. Econ. Law 2015, 4, 10. [CrossRef]

37. Piwowarski, J. Fenomen Bezpieczeństwa. Pomiędzy Zagrożeniem a kultura Bezpieczeństwa; Wyższa Szkoła Bezpieczeństwa Publicznego i Indywidualnego „Apeiron” w Krakowie: Kraków, Poland, 2015; p. 47.

38. Chodyński, A. Bezpieczeństwo Jako Wymiar Kultury Organizacji a Zewnętrzne Zróżnicowanie Kulturowe: Kontekst Organizacyjny i Społeczny. In Bezpieczeństwo, Teoria i Praktyka, Kultura Bezpieczeństwa, Uwarunkowania Społeczne i Organizacyjne; Chodyński, A., Ed.; Kwartalnik Krakowskiej Akademii im. Andrzeja Frycza Modrzewskiego: Kraków, Poland, 2018; Volume 4, p. 45.

39. Commission Delegated Regulation (EU) 2018/762 of 8 March 2018 Establishing Common Safety Methods on Safety Management System Requirements Pursuant to Directive (EU) 2016/798 of the European Parliament and of the Council and Repealing Commission Regulations (EU) No 1158/2010 and (EU) No 1169/2010. Available online: https: / / eur-lex.europa.eu/legal-content/ EN/TXT/HTML/?uri=CELEX:02018R0762-20200616\&from=PL (accessed on 10 June 2021).

40. Wilson, J.R. Fundamentals of systems ergonomics/human factors. Appl. Ergon. 2014, 45, 5-13. [CrossRef]

41. Habib, T.; Komoto, H. Comparative analysis of design concepts of mechatronics systems with a CAD tool for system architecting. Mechatronics 2014, 24, 788-804. [CrossRef]

42. Riel, A.; Kreiner, C.; Messnarz, R.; Much, A. An architectural approach to the integration of safety and security requirements in smart products and systems design. CIRP Ann. 2018, 67, 173-176. [CrossRef]

43. Saaty, R.W. The analytic hierarchy process-what it is and how it is used. Math. Model. 1987, 9, 161-176. [CrossRef]

44. Vester, F. Denken, Lernen, Vergessen [Thinking, Learning, Forgetting]; Deutsche Verlags-Anstalt: Stuttgart, Germany, 1975; Pocketbook Edition, 1978 (27th Edition, 2001). Munich: Dtv.

45. Vester, F. Ballungsgebiete in der Krise [Urban Areas in Crisis]; Deutsche Verlags-Anstalt: Stuttgart, Germany, 1976; Pocketbook Edition, 1983 (5th Edition, 1994). Munich: Dtv.

46. Vester, F. Unsere Welt_ein Vernetztes System [Our World-a Networked System]; Klett-Cotta: Stuttgart, Germany, 1978; Pocketbook Edition, 1983 (10th Edition, 1999). Munich: Dtv.

47. Vester, F. Ökolopoly, ein Kybernetisches Umweltspiel von Frederic Vester [An Environmental Cardboard Game]; Otto Maier Verlag: Ravensburg, Germany, 1984.

48. Vester, F. The bio-cybernetic approach as a basis for planning our environment. Syst. Pract. 1988, 1, 399-413. [CrossRef]

49. Vester, F. Ökolopoly PC-Version, Das Kybernetische Umweltspiel von Frederic Vester [An Environmental Computer Game]; Studiengruppe für Biologie und Umwelt GmbH: Munich, Germany, 1989. 